Meta

Journal des traducteurs

Translators' Journal

\title{
Analysis of the Translator's Strategy in the Translator-Initiator Game from the Perspective of Game Theory
}

\section{Bi Zhao}

Volume 60, numéro 2, août 2015

$60^{\mathrm{e}}$ anniversaire. Les horizons de la traduction : retour vers le futur $60^{\text {th }}$ Anniversary. Translation's Horizons: Back to the Future

60mo aniversario. Los horizontes de la traducción: regreso al futuro

URI : https://id.erudit.org/iderudit/1032929ar

DOI : https://doi.org/10.7202/1032929ar

Aller au sommaire du numéro

Éditeur(s)

Les Presses de l’Université de Montréal

ISSN

0026-0452 (imprimé)

1492-1421 (numérique)

Découvrir la revue

Citer ce document

Zhao, B. (2015). Analysis of the Translator's Strategy in the Translator-Initiator Game from the Perspective of Game Theory. Meta, 60(2), 378-378.

https://doi.org/10.7202/1032929ar d'utilisation que vous pouvez consulter en ligne. 


\title{
Analysis of the Translator's Strategy in the Translator- Initiator Game from the Perspective of Game Theory
}

\author{
BI ZHAO \\ Shanghai International Studies University, Shanghai, China \\ zhaob@shisu.edu.cn
}

Interdisciplinary translation studies have yielded rich results in China since the 1990s, but the majority of such research has been confined within a small section of the discipline of liberal arts including mainly literature, art and culture, with few approaches observed beyond that boundary. A compositional part of the attempt to go beyond that boundary is to introduce the concept of the well-developed game theory into translation studies. This paper, on the basis of defining the interaction between the translator and the initiator of the translation task as a game, first analyzes the three categories of personality which constitute the initiator of the translation task, and examines how a different constituent of the role of initiator in this game changes the interaction pattern between the translator and the initiator, including the procedure of the game, the power relation between the two players of this game, and the strategy of each player. Then it looks into the relationship between the translator's strategy and his/her payoff in the translator-initiator game, or more specifically, whether the translator adopts a certain strategy, consciously or subconsciously, out of the purpose to maximize his/her payoff in this game. Finally, this paper analyzes how the difference in location (Canada and China) causes the translator to change his/her strategy in the translator-initiator game with a case study. The findings of this paper show that the translator's strategy in the translator-initiator game is not an independent decision made solely out of the translator's own preference, but a rational choice made to achieve the translator's own maximum utility in this game.

Bi Zhao is a Chinese scholar who received all his university degrees and teaching experience from Shanghai International Studies University, with two stints abroad as a visiting scholar at Boston University, USA and at Christchurch Polytechnic Institute of Technology, New Zealand. His academic interests include: translation and game theory, translation technology, translation pedagogy, retranslation and audiovisual translation. 